\section{The Janus Face of Homeownership-based Welfare}

\author{
Marja Elsinga
}

Faculty of Architecture and the Built Environment Delft University of Technology, Delft, Netherlands M.G.Elsinga@tudelft.nl

\section{Joris Hoekstra}

Faculty of Architecture and the Built Environment Delft University of Technology, Delft, Netherlands J.S.C.M.Hoekstra@tudelft.nl

\begin{abstract}
This paper reflects on the different faces of asset-based welfare from both a theoretical and an empirical perspective. It shows that asset-based welfare can be perceived as a lever for welfare state restructuring but also as an instrument for poverty eradication. In most countries, asset-based welfare policies focus on stimulating home-ownership. The general idea is that by becoming a homeowner, households build up equity that can be released for care and pension purposes in old age. However, there are signs that such policies increase inequality between homeowners (depending on the location of the dwelling and/or the period in which it was bought), but particularly so between homeowners and tenants. We therefore contend that home-ownership based welfare policies need a clear and fundamental specification of the role of the government: how to deal with housing market risks and how to prevent politically unacceptable levels of inequality and exclusion?
\end{abstract}

Keywords: asset-based welfare; social policy; inequality; governments. 


\section{Introduction}

Housing-asset consumption among the elderly population seems to have become a topic of heated debate in the Netherlands. At a symposium organised by the scientific board for government policy (WRR) in 2013, thinkers from the political right and left voiced their worries about releasing housing assets for welfare purposes. The left-wing thinkers were concerned about people, such as tenants, without housing assets. The right-wing thinkers feared that people who possess considerable housing assets would be obliged to consume these assets first before they would be entitled to welfare provisions.

The Netherlands is a country with huge pension funds, a huge mortgage debt and a huge social rental sector; a country that seems remote from the homeownership-based welfare described by Doling and Ronald (2010). However, in the Netherlands housing is also more and more connected to welfare and pensions in policy discourse, not least because the Dutch government subsidises both homeownership and pension-saving (Asbeek and Montfort 2013). Combining them therefore seems a logical way to cut budget expenditures.

This paper reflects on asset-based welfare from both a theoretical and an empirical perspective. First, we describe the theory behind asset-based welfare and the application of this concept in 'real-life' policies. Where does the concept come from? Is it a way to get rid of the collective public welfare state? Or is it a rigorous redistribution of assets within a society? Second, we present some empirical evidence on the role that asset-based welfare plays in various European countries. We end with a reflection on the implications of asset-based welfare for the future of European welfare states.

\section{The Basics of Asset-based Welfare and the Role of Housing}

Asset-based welfare dates back to the 1880s when among campaigners for land distribution 'three acres and a cow' became a popular slogan expressing the ideal land holding for every citizen (Gamble and Prabhakar 2005). Later on, the emphasis shifted from land to other assets. Skidelsky, for example, argues that all individuals in an economy should receive an unconditional grant of resources (stock of capital), which will give the poor a platform to reach a standard of living from where they can move forward on their own towards prosperity. According to Skidelsky (2001): 'This grant of resources can be attained by redistribution: a transfer from the rich to the poor. Redistribution should be undertaken till the point where the negative marginal utility of the rich by sacrifice of some assets (or income) exactly offsets the positive marginal utility of the poor by gaining of assets.' Asset-based policies provide needy households with the means and opportunities to accumulate assets and have greater control over their livelihoods. To be successful, an asset-based policy should overcome challenges such as initial inequality, unorganised sectors of the economy, imbalance in asset-building and inadequate state effectiveness. In order to have sustainable development based on asset-based policies, public intervention to increase access to assets such as land, housing and credit is important (Moser and Anis 2008). A specific instrument of asset-based welfare in the US is the Individual Development Account (IDA). The IDA is an asset-building tool designed to enable low-income families to save towards a target amount of money, usually used for building assets in the form of homeownership, post-secondary education and small business ownership. In principle IDAs work as matched savings accounts that supplement the savings of low-income households with matching funds drawn from a 
variety of private and public sources (Gamble and Prabhakar 2005). Affordable homeownership schemes can also be considered asset-based welfare policies (Sherraden 2003).

Sherraden (2003) argues that assets and savings accumulation requires institutional structures and incentives and that asset-based development policies can have psychological, social and economic impacts: 'income polies feed the stomach, but asset based policies change the mind'. This idea of an asset-based welfare policy is criticised, for example, by Emmerson and Wakefield (2001), who doubt the independent effect of asset-owning on individual life chances. They argue that the existing evidence on this effect is not strong enough to justify a large-scale programme of asset-based welfare policies. However, they also state that engaging in the process of asset building, and thereby learning to plan ahead and learning about financial institutions, can help poorer people to have more opportunities in life (Emmerson and Wakefield 2001).

\section{The Role of Housing}

Whereas the general literature on asset-based welfare pays attention to wealth redistribution and poverty eradication without particularly focusing on housing, 'real-life' asset-based welfare policies tend to concentrate on housing assets. In the US, asset-based welfare policies started as an antipoverty strategy; assets were deemed to be a way of empowering lowerincome groups, with homeownership being considered as the key asset (Paine 1987; Sherraden 2003). Housing literature focusing on the UK tends to see (housing) asset-based welfare as a lever for welfare-state restructuring. In this respect, home equity is considered a private safety net and an alternative to collective welfare arrangements. Indeed, research on Kemeny's famous trade-off hypothesis has shown that there is a negative relationship between the size of the homeownership sector and the extent of the welfare state (Castles 1998; De Wilde and Raeymackers 2008). Thus, housing policy appears to be strongly intertwined with social policy and ideas about the welfare state, and policies that attempt to promote homeownership may also be regarded as policies aimed at less collective welfare arrangements.

According to Groves et al (2007): 'Housing is no longer a wobbly pillar of the welfare state alongside a generous, redistributive welfare system.' Instead, housing has become the cornerstone for a more individualistic economic and social policy agenda. By investing in homeownership, citizens take responsibility for their own welfare in different stages of life (Groves et al 2007). Doling and Ronald (2010) approach asset-based welfare from a similar perspective: 'The principle underlying an asset-based approach to welfare is that, rather than relying on state-managed social transfers to counter the risks of poverty, individuals accept greater responsibility for their own welfare needs by investing in financial products and property assets which augment in value over time. These can, at least in theory, later be tapped to supplement consumption and welfare needs when income is reduced, for example, in retirement, or used to acquire other forms of investment such as educational qualifications.' (Doling and Ronald 2010: 166)

In the housing literature the emphasis is on the release of housing equity for care and pension purposes. This is seen as a solution for income-poor but asset-rich people in old age, and may help to ease the pensions problem in ageing societies such as the UK and a number of EastAsian countries (Doling and Ronald 2010; Groves and Watson et al 2007). Until now, the 
housing asset-based welfare debate has seemed to concentrate on Anglo-Saxon and East Asian societies. In these countries the release of housing equity by mortgage products is more common. Nevertheless, equity release and the debate on asset-based welfare are also gaining importance in the relatively generous welfare regimes of continental Europe.

\section{Empirical Evidence so far: International Experiences}

\section{Paradoxes in homeownership-based welfare}

European and Asian governments both consider the release of housing equity to be a solution for the pension problems of ageing societies. Ronald (2013) provides a picture of three Asian countries (Japan, South Korea and Singapore) and discusses the complicated role of housing in welfare systems. Encouraging home ownership appears to be an important policy measure in all three countries. However, there is a paradox involved: how to combine the interests of insiders (who prefer prices to increase) and outsiders (who prefer low house prices)? If house prices rise faster than incomes, homeownership becomes more and more expensive. A policy enabling access to homeownership for lower-income groups will therefore become more and more costly over time and may in itself propel further house prices increases. The question is what role governments intend to play in this respect. Smith (2006) states that in the absence of active governance around the use of housing wealth, whole economies and entire housing systems are susceptible to the risk embedded in a new financial order of owner-occupation. She also points at another paradox: can a risky business turned into a safety net? Montgomerie and Budenbunder (2014) also point to this in their evaluation of asset-based welfare in the UK. They conclude in clear words that the asset-based welfare approach in the UK has failed; it has led to a debt burden that threatens economic stability as well as social cohesion.

\section{Asset-based welfare, household strategies}

It is clear that asset-based welfare has implications for the role of housing in household strategies as well as in housing policy. Elsinga et al (2007) distinguish three ways in which homeownership-based welfare can play a role in household behaviour: households consider homeownership to be an asset; households use housing equity in their financial planning; households take housing equity into account for their safety net and welfare needs. Based on 240 interviews in eight countries, it appears (Elsinga et al (ibid.)) that although a roof over one's head was usually the most important reason to buy, housing equity was an argument mentioned in all eight countries when interviewees explained their choice for homeownership. Interviewees said they would rather pay money into their own pocket than into a landlord's pocket. The security of being a homeowner was not always self-evident, however. This depended on the income of the household and the extent to which the mortgage has been repaid. In some countries and for some groups of people (e.g. low-income households, households with unstable relationships or households without a steady job) renting was perceived as preferable for security reasons, either as a temporary solution (Finland, Belgium and the UK) or as a long-term acceptable alternative (Germany, Sweden, the Netherlands), depending on the national housing policies that dictate the security of renting. Renting was seen only as a last resort, and, in Hungary and Portugal, as intended for people with no financial opportunities. In those two countries moreover tenants were perceived as being socially excluded. In Hungary, homeownership was also described as insecure, since the timing and the process of buying could have far-reaching consequences for the rest of 
people's lives. Moreover, the quality of the dwellings caused insecurities (Elsinga et al 2007; Jones et al 2007; Toussaint 2011).

Homeownership can a benefit as an asset in three ways: first, housing expenses are lower once the mortgage is repaid; second, the house can be sold and the proceeds used; and third, the withdrawal of mortgage equity. According to studies (Toussaint 2011), lower housing expenses in old age appear to be a common phenomenon, whereas households tend to be more troubled by the idea of selling their home and mortgage equity withdrawal in the event of a drop in income. In all countries, people seem cautious about accessing housing equity and refer to their homes as a 'sanctuary' that should not be caught up too much in economic considerations. Most people seem to strive towards outright ownership, and wish to pass the capital on to their children and are hesitant to buy equity release products. The complexity of these products is feared and the providers of them often face mistrust (Toussaint 2011).

\section{Asset-based welfare and the role of the rental sector}

The preceding paragraphs have shown that, as far as housing is concerned, asset-based welfare tends to be linked to the homeownership sector. Within this sector, it may cause inequality between privileged homeowners whose dwelling is located at a good location, and less-privileged homeowners whose dwelling is located in a deprived neighbourhood. However, the real divide in a society that is based on homeownership based welfare is that between homeowners and tenants. Whereas homeowners have the opportunity to build up assets in their dwelling, with all the risks associated with this, tenants do not have such an option. In other words, 'real-life' homeownership-based welfare policies are considerably less inclusive than the founders of the asset-based welfare concept (see Section 2) envisaged. Rather than solving inequality, they tend to create new inequalities along the lines of tenure distribution. This raises the question how to deal with the (social) rental sector in a society in which asset-based welfare is becoming increasingly important? In our opinion, two main responses can be discerned.

First of all, there are countries that are actively attempting to make the homeownership sector as large as possible. Fiscal measures and subsidies for homeownership are instruments that are often applied for this purpose. In the literature (Kemeny 1981; Malpass 2008), such countries are often termed 'homeownership societies. In homeownership societies, the function of the social rental sector can be twofold. First of all, it performs the function of a safety net for households with the lowest incomes. Secondly, the social rental sector may be seen as a stepping stone to homeownership. Right-to-buy policies, such as in the UK (Jones and Murie 2006), can be implemented in order to give social rental tenants the opportunity to become homeowners and to build up assets. In the course of time, when the social rental sector gets smaller and more residual, this second function generally loses importance. Norris and Fahey (2011) have convincingly described this process for the case of Ireland. Right-tobuy policies are not the only policy measures that can make homeownership and assetbuilding more accessible. Various homeownership societies have also implemented forms of social homeownership (e.g. in Spain, see Hoekstra et al 2010) and intermediate tenures (e.g. in the UK, see Monk and Whitehead 2010). These tenure arrangements particularly aim to make the homeownership sector more accessible and affordable for middle-income households. Nevertheless, not everyone can become a homeowner. Those who remain tenants are dependent on the limited welfare provisions of the state and generally don't have the opportunity to build assets. 
Second, there are the countries with a relatively large and well-regulated rental sector, such as France, Germany, Sweden and the Netherlands. In these countries, the rental sector is generally seen as a viable relatively long-term alternative for lower- and middle-income households. Although there is certainly no lack of policies that stimulate homeownership, housing policies are on average more tenure-neutral than in homeowning societies. These countries are characterised by a relatively large social rental sector (France, Sweden, the Netherlands) and often have developed policies (taxation measures, rent regulation, subsidies) that make the private rental sector attractive and secure for both tenants and landlords. Both Germany and France are good examples of this. In Germany, private rental landlords can receive financial support if they rent out their dwelling for a particular time period against a moderated rent to a household with a lower income. France has a somewhat similar system in which tax incentives are available for both individual and institutional private rental landlords. The difference is that the German subsidised private rental sector forms a substitute for the social rental sector (a real social rental sector is missing in Germany), whereas in France the subsidised private rental sector - also called the intermediary rental sector - comes on top of the traditional social rental sector (Haffner et al 2009). After 2000, some countries with a broad social housing model (e.g. the Netherlands, Sweden) came under scrutiny from the European Commission owing to questions about fair competition (Elsinga et al. 2008, Elsinga and Lind, 2013). In the Netherlands, this has resulted in new housing allocation rules for social rental dwellings that have substantially limited the access of middle-income groups to the social rental sector (Hoekstra and Boelhouwer 2014).

Broadly speaking, homeownership societies tend to have a more residual welfare state, with more importance attached to asset-based welfare and neo-liberal policies, than do societies with a relatively large rental market. However, this is not by definition the case. For example in 'home-owning' Norway, the welfare state remains relatively strong. Moreover, policies promoting homeownership in this country have actually had a decommodifying effect; they have resulted in wealth redistribution within the homeownership sector (Stamsø 2008). The Norwegian example clearly shows that the relationship between welfare and housing policies is context-dependent.

\section{The future of 'generous' welfare states}

In the last seven years, the Global Financial Crisis seems to have resulted in an accelerated welfare state retraction and rising popularity for the concept of asset-based welfare. The question is how this trend will affect the relatively large rental markets in countries such as France and Germany. Will the middle-income tenants in these countries be 'forced to move' to the homeownership sector (in order to be able to build assets and/or as a result of European Union regulations) or will their governments develop redistributive policies that allow for a transfer of wealth between the home-owning sector and the rental sector (for example by imposing a substantial wealth tax on homeownership)? The availability of suitable investment and saving opportunities outside the homeownership sector also plays a role here, particularly for middle-income groups. Given their high housing costs, building up assets outside the housing sector (saving accounts, stocks, trust funds etc.) is probably not a viable option for tenants with low income. 


\section{Conclusion and discussion}

Asset-based welfare appears to have two faces. The first is the face of poverty-alleviation achieved by providing people with assets, homeownership being a self-evident example. The second face is housing equity as a solution to the care and pension problems of older homeowners in a retracting welfare state. The Janus faced nature of the asset-based welfare concept means it is looked on with suspicion by both left-wing and right-wing thinkers. Nevertheless, the concept is clearly gaining momentum.

Research evidence so far is at least reason to have some doubts about the concept of homeownership-based welfare. There are signs that current asset-based policies (e.g. those in the UK) increase inequality. Moreover, the current debate is focussed on homeownership and more or less ignores the position of tenants. Thus, current asset-based welfare policies are far from being inclusive. Also, there is the fundamental question of whether it is at all possible to turn the risky business of homeownership into a safety net.

Therefore, when the role of housing and welfare is considered, it is important to be coherent in policy choices about the role of housing assets in welfare policies, in particular for pensions and care in old age. In practice, such coherence is often lacking when housing equity is considered. Are housing assets considered superfluous, a pillar of the pension system or a cornerstone of the welfare state? In the first case, there is no clear vision on welfare and those who have housing equity are lucky to be able to use it in old age. The second option is to see housing assets as a fourth pillar of the pension system: next to public pensions (and public welfare), company pensions and private assets. Assigning housing the position of the fourth pillar in pension provision may enable reductions in other pillars of public welfare provision, but this requires a clear view of how tenants can be included in this idea. Finally, housing could be considered a real cornerstone of welfare states. However, such a policy needs a clear and fundamental specification of the role of the government: how to deal with housing market risks and how to prevent politically unacceptable levels of inequality and exclusion? Experiences from the US and Singapore make clear that homeownership-based welfare is a risky business that can only really work with huge government interference.

A task for researchers is to collect evidence on the application of these three options in different countries thus to gain knowledge on asset-based welfare policies and their effects at the juncture of welfare and housing. 


\section{References}

Asbeek Brusse, W., C. J. van Montfort 2013. Wonen, Zorg en Pensioenen; Hervormen en Verbinden; Den Haag Wetenschappelijke Raad Voor Regeringsbeleid.

Braga, M., P. Palvarini 2013. Social Housing in the EU. Brussels: EC: Policy Department Economic and Scientific Policy.

Castles, F. G. 1998. 'The Really Big Trade-off: Home Ownership and Welfare State in the New World and the Old.' Acta Politica 33 (1): 5-19.

De Wilde, C., P. Raymaeckers 2008. 'The Trade-off between Home Ownership and Pensions: The Individual and Institutional Determinant of Old Age Poverty.' Ageing and Society 28: 805-830. DOI: http://dx.doi.org/10.1017/S0144686X08007277.

Doling, J., R. Ronald 2010. 'Home Ownership and Asset-based Welfare.' Journal of Housing and the Built Environment 25: 165-173. DOI: 10.1007/s10901-009-9177-6.

Doling, J., M. Elsinga, 2013. Demographic Change and Housing Wealth: Homeowners, Pensions and Asset-based Welfare in Europe. Dordrecht, Heidelberg, New York, London: Springer.

Elsinga, M., P. De Decker, N. Teller, J. Toussaint (eds.) 2007. Home Ownership beyond Asset and Security, Housing Related Security and Insecurity. Amsterdam: IOS Press.

Elsinga, M., M. Haffner, H. van der Heijden 2008. 'Threats to the Dutch Unitary Rental Market' International Journal of Housing Policy 8 (1): 21-37. DOI: 10.1080/14616710701817141.

Elsinga, M., H. Lind 2013. 'The Effect of EU-legislation on Rental Systems in Sweden and the Netherlands.' Housing Studies 28 (7): 960-971. DOI: $10.1080 / 02673037.2013 .803044$.

Emmerson, C., M. Wakefiled 2001. The Saving Gateway and the Child Trust Fund: Is Asset-based Well Fare "Well Fair"? London: The Institute for Fiscal Studies.

Gamble, A., R. Prabhakar 2005. Assets and Poverty, ESRC End of Award Report Form RES-000-23-0053 Nominated Output 2.

Groves, R., A. Murie, C. Watson 2007. Housing and the New Welfare State: Examples from East Asia and Europe. Aldershot: Ashgate.

Haffner, M. E. A., J. S. C. M. Hoekstra, M. J. Oxley, H. M. H. van der Heijden 2009. Bridging the Gap between Social and Market Rented Housing in Six European Countries? Amsterdam: 1OS Press.

Hoekstra, J., I. Heras Saizarbitoria, A. Etxezarreta Etxarri 2010. 'Recent Changes in Spanish Housing Policies: Subsidized Owner-occupancy Dwellings as a New Tenure 
Sector?' Journal of Housing and the Built Environment 25 (1): 125-138. DOI: 10.1007/s10901-009-9169-6.

Hoekstra, J. S. C. M, P. J. Boelhouwer 2014. 'Falling between Two Stools? Middleincome Groups in the Dutch Housing Market.' International Journal of Housing Policy 14 (3): 301-313. DOI: 10.1080/14616718.2014.935105.

Jones, C., A. Murie 2006. The Right to Buy, Oxford: Blackwell.

Jones, A., M. Elsinga, D. Quilgars, J. Toussaint 2007. 'Home Owners' Perceptions and Responses to Risk' European Journal of Housing Policy 7 (2): 129-150. DOI: http://dx.doi.org/10.1080/14616710701308539.

Kemeny, J. 1981. The Myth of Home Ownership. London: Routledge \& Kegan Paul.

Malpass, P. 2008. 'Housing and the New Welfare State: Wobbly Pillar or Cornerstone?' Housing Studies 23(1): 1-19. DOI: http://dx.doi.org/10.1080/02673030701731100.

Monk, S., C. Whitehead 2010. Making Housing More Affordable. Oxford: WileyBlackwell.

Montgomerie, J., M. Budenbender 2014. 'Round the Houses: Home Ownership and Failures of Asset-based Welfare in the United Kingdom.' New Political Economy: 1-20. DOI: $10.1080 / 13563467.2014 .951429$.

Moser, C., A. A. Dani (eds.) 2008. Assets, Livelihoods, and Social Policy. Washington, DC: World Bank Publications.

Norris, M., T. Fahey 2011. 'From Asset Based Welfare to Welfare Housing? The Changing Function of Social Housing in Ireland' Housing Studies 26 (3): 459-469. DOI: 10.1080/02673037.2011.557798.

Paine, T. 1987. 'Agrarian Justice’ Pp. 471-489 in M. Foot, I. Kramnick (eds.) The Thomas Paine Reader. Harmondsworth: Penguin.

Paxton, W. 2003. 'Introduction' in W. Paxton (ed.) Equal Shares? Building a Progressive and Coherent Asset-based Welfare Policy. London: Institute for Public Policy Research.

Ronald, R. 2013. Lessons from East Asia, Pp. 119-136 in J. Doling, M. Elsinga. Demographic Change and Housing Wealth: Homeowners, Pensions and Asset-based Welfare in Europe. Dordrecht, Heidelberg, New York, London: Springer.

Sherraden, M. 2003. Assets and the Social Investment State. Pp. 28-41 in W. Paxton (ed.) Equal Shares: Building a Progressive and Coherent Asset-based Welfare Strategy. London: Institute for Public Policy Research.

Skidelsky, R. 2001. Asset Based Welfare. Retrieved July 6, 2015, from http://www.skidelskyr.com/site/article/asset-based-welfare/ 
Smith, S. 2006. 'Managing a Risky Business.' In: J. Doling, M. Elsinga (eds.) Home Ownership: Getting in, Getting from, Getting out. Amsterdam: IOS.

Stamsø, M. A. 2008. 'Housing and the Welfare State in Norway.' Scandinavian Political Studies 32 (2): 195-220. DOI: 10.1111/j.1467-9477.2008.00223.x.

Toussaint, J., 2011. Housing Wealth in Retirement Strategies; Towards Understanding and New Hypotheses. Amsterdam: 1OS Press. 